\title{
ZOOTECHNICAL AND GENETIC ASPECTS OF A PROLIFIC MERINO PROGRAM
}

\author{
K. MAgYAR ${ }^{1}$, L. Veress ${ }^{2}$, Zs. TASI ${ }^{2}$, T. PÉCSI $^{2}$, S. BABIK ${ }^{2}$ and Irén HORVÁth ${ }^{2}$ \\ ${ }^{1}$ Department of Animal Physiology and Health and ${ }^{2}$ Department of Animal Breeding, \\ University of Agriculture, H-4032 Debrecen, P.O. Box 36, Hungary
}

(Received October 23, 1997; accepted March 10, 1998)

\begin{abstract}
In a Prolific Merino nucleus herd of 200 ewes the ovulation rate (OR) test results obtained in 169 animals between 1988 and 1993 were compared with those of 113 ewes from the same herd in 1996. Whereas earlier the ratio of individuals showing an OR $\geq 4$ was only $32 \%$, that of the group checked in 1996 was $59 \%$. This increase could be attributed to 40 ewes, both of whose parents had proven to be homozygous carriers of the prolific gene. To develop the Prolific Merino breed, 21 Booroola Merino rams were imported from New Zealand, and mostly their frozen semen was used. Of these rams, one was not a prolific gene carrier, 8 were homozygous carriers, 10 were heterozygous carriers and two had not been identified yet. Of the 36 home-bred rams, 9 proved to be homozygous by parents, 11 heterozygous, 8 homozygous, one proved to be a non-carrier, and 7 rams and their frozen semen were to be progeny tested. Six thousand doses of frozen semen from a total of 33 animals (16 imported rams and their 17 home-bred offspring) are stored in plastic straws. Sixty-three $\%$ of this is semen reserve from rams of the $\mathrm{Fec}^{\mathrm{B}} \mathrm{Fec}^{\mathrm{B}}$ genotype, belonging to 10 ram lines. The remaining $37 \%$ is gene reserve intended for creating homozygous ram lines. Only one ram (no. 3244) was bought for the nucleus herd, the other ram lines were introduced into the herd by assortative mating, using intrauterine insemination. The average conception rate found after 472 intrauterine inseminations was $53 \%$ with large (occasionally 10 $100 \%$ ) individual ram differences.
\end{abstract}

Key words: Prolific Merino, $\mathrm{Fec}^{\mathrm{B}}$ gene, intrauterine insemination, assortative mating, ovulation rate

The Prolific Merino, introduced to Hungary as a new breed in 1992, results from crossing the prolific gene carrier Booroola Merino rams with the local Merino breed. The nucleus herd of the breed, consisting of 200 ewes and kept in Debrecen, has been selected for homozygosity of the $\mathrm{Fec}^{\mathrm{B}}$ gene to improve the ewes' lambing frequency, to achieve a higher growth rate of lambs, a higher mature liveweight, and to maintain the capacity of producing fleece of $\geq 9 \mathrm{~cm}$ staple length and a fineness of 20-22 microns. Several studies have reported the breeding and progeny performance of the herd (Veress et al., 1995; Magyar et 
al., 1997). The aim of the present study was to provide new information on the regular ovulation rate $(\mathrm{OR})$ tests carried out in the herd, on the results of intrauterine inseminations, and on the genealogical linebreeding carried out there.

\section{Materials and methods}

When the herd was established in 1988, 93 females were bought, some of which were homozygous and heterozygous gene carriers. In the ewe and hogget flock, the number of corpora lutea (CL) was recorded laparoscopically 5-8 days after mating according to Hulet and Foot (1968) as modified by Magyar (1988). The test gives reliable results only if it is repeated at least three times (Piper and Bindon, 1982). Litter size is inherited with partial dominance, while the OR in an additive way (Piper et al., 1985; Dodds et al., 1991). In flocks lambing once a year, OR tests have been performed by other authors mostly in autumn, when day-length is getting shorter. In the flock included in this study, the rate of frequent lambing as a genetic trait tended to increase. Under such circumstances the animals having an OR $\geq 4$ were expected to be homozygous carriers of the $\mathrm{Fec}^{\mathrm{B}}$ gene. However, this hypothesis can only be proven later, when detailed data become available.

Until the end of 1991, when the qualification of the Prolific Merino breed was completed, non-carriers of the gene could not be selected. Later on the flock was checked for the most important infectious diseases (e.g. brucellosis, chlamydiosis, leptospirosis and maedi-visna), and serologically positive individuals were removed. In this way the flock could join the international breeding integration.

The ewes were inseminated or mated partly with home-bred, partly with imported rams. In May-June and in December-January mostly an own-bred ram was introduced into the flock in order to shorten the mating and lambing periods. If possible, intrauterine insemination was applied and OR tests were not performed. Although the average results of three OR tests were not available in all cases, an increasing rate of the homozygous $\mathrm{Fec}^{\mathrm{B}}$ gene carriers was expected in the flock.

Between 1980 and 1989, 29 rams and their frozen semen were purchased from Booroola Merino breeding stocks in New Zealand and Australia. It was considered essential to store frozen semen from the highest possible number of rams and their offspring in Hungary. To dilute the semen, the extender recommended by Salamon (1976) was used in a solution of 1:4 in $0.25 \mathrm{ml}$ Cassou's straw. Each inseminating dose contained 50 million viable cells with progressive motility. Deep-freezing of semen was carried out according to the method described by Tasi et al. (1984).

Intrauterine insemination was carried out by the method of Killen and Caffery (1982) and McKelvey et al. (1985), as modified by Magyar et al. (1989a,b). In 
the past two years a special plastic pipette was used for intrauterine inseminations (Magyar, 1994).

It was necessary to check which of the rams from New Zealand and their offspring born in Hungary were carriers of the prolific gene. The nine rams purchased between 1980 and 1982 were estimated and ranked by the progeny indicators of their daughters from the first crossing (Veress, 1991; Magyar et al., 1991). Later the rams to be progeny tested were mated with ewes not carrying the prolific gene, and in their 5-month-old daughters weighing $28 \mathrm{~kg}$ or more, ovulation was induced by injecting 625 IU PMSG. The OR test was conducted 5-8 days later according to the method of Cleverdon and Hart (1981). By this method other authors, e.g. Davis and Kelly (1983), Oldham et al. (1984), Davis and Johnstone (1985) estimated the breeding value of rams, thus shortening the time of progeny tests by one year. In this study, the semen was used for intrauterine insemination and the semen of imported as well as home-bred rams was stored. The breeding value of the rams was estimated by checking a certain part of their offspring. The rams were considered to be of $\mathrm{Fec}^{\mathrm{B}} \mathrm{Fec}^{\mathrm{B}}$ genotype if they had $\mathrm{Fec}^{\mathrm{B}} \mathrm{Fec}^{+}$daughters from ewes not carrying the prolific gene. If ewes of $\mathrm{Fec}^{\mathrm{B}} \mathrm{Fec}^{\mathrm{B}}$ genotype mated with the given ram produced only heterozygous daughters, the ram was qualified as a non-carrier (e.g. ram no. 73211). If about half of their daughters were heterozygous and the other half homozygous, the ram was qualified as having a heterozygous genotype. The semen of rams not yet progeny tested was stored frozen.

\section{Results and discussion}

\section{Ovulation rate $(\mathrm{OR})$ tests}

So far, the OR test is the simplest and least expensive method for detecting the presence of the prolific gene. The results of OR tests carried out once or several times in 163 animals between 1988 and 1993 and in 113 animals in 1996 are available. These results are compared in Table 1 . In the first case $32 \%$, in the second case 59\% of the animals reached an OR of 4 or higher. In 1996 there were 40 ewes in the herd whose parents were qualified to be homozygous carriers of the prolific gene, but their own OR results were not available. In this way $75 \%$ of the ewes in the herd were estimated to be homozygous.

From 1996, the homozygous gene carriers were selected for higher body weight, hornlessness, and better mothering abilities, which were to be further improved in the breeding program. The female offspring were OR tested, the males progeny tested, and the heterozygotes selected. Even in 1996 there were first-lambing ewes with low OR results. The offspring of two rams had an ex- 
cellent phenotype, but based on the progeny test only one of them (no. 910) proved to be $\mathrm{Fec}^{\mathrm{B}} \mathrm{Fec}^{+}$, while the other one (no. 73211) had $\mathrm{Fec}^{+} \mathrm{Fec}^{+}$genotype (Table 1). The latter ram originated from heterozygous parents.

Great emphasis was laid on frequent lambing, because this trait was found to be of moderate heritability, $\mathrm{h}^{2}=0.28-0.32$ (Veress et al., 1993). This is why although the ratio of animals carrying the gene on one of their alleles only has been increasing for years, the average progeny rate possibly does not exceed $160-170 \%$ in the case of first-lambing ewes, and $200 \%$ in ewes that have lambed several times. It is supposed that embryo mortality is higher in the frequent lambing system than in flocks lambing once a year.

\section{Deep-freezing of semen}

The importation of rams from New Zealand to Hungary is expensive and complicated. Therefore, in 1980 the collection and freezing of semen from the first purchased rams were started. When the quarantine period of rams purchased for the third time was over, 200-300 doses of semen from each ram were frozen in 1986. Later on, semen from home-bred rams of excellent qualities (e.g. larger liveweight, hornlessness, longer and finer staple, etc.) was added to this semen reserve (Table 2 and Fig. 1).

So far, 500 doses of semen have been used for assortative mating in the flock, more than 1,500 doses for the rams' progeny test, and 500 doses have been exported. At present the semen of nine imported and 24 home-bred rams is being stored. Sixty-three \% of this is from homozygous genotype. Part of the semen is only gene reserve, but a considerable amount is available for assortative mating in the own herd.

The libido of the Booroola and the Prolific Merino is perfect. The volume per ejaculate is about $1-1.5 \mathrm{~cm}^{3}$, and sperm motility is acceptable even after the season. Its value is similar to that of other Merino breeds. However, like that of other species such as cattle, the semen of some rams is not suitable for deepfreezing (see Table 5).

\section{Linebreeding}

The first carrier of the prolific gene recorded in Australia was possibly only a single ewe. Our rams were purchased from the breeding stock of Haldon Station in New Zealand. They purchased rams and ewes from Don Robertson, an Australian breeder, but farmer data on the origin of these animals were not available or perhaps such data were not recorded at all. Several imported rams (no. 8502, 4130, 59, 5140) were inbred, but it cannot be excluded that most of them represent offspring of accumulated inbreeding. 
Table 1

Ovulation rate (OR) results in the nucleus flock of Debrecen

\begin{tabular}{|c|c|c|c|c|c|c|c|c|c|c|c|}
\hline \multirow{4}{*}{ OR } & & \multirow{2}{*}{\multicolumn{2}{|c|}{ Ewe lambs }} & \multicolumn{4}{|c|}{ Mature ewes } & \multicolumn{4}{|c|}{ Total } \\
\hline & & & & \multicolumn{2}{|c|}{ One examination } & \multicolumn{2}{|c|}{ More than one examination } & \multicolumn{2}{|c|}{ 1988-1993 } & \multicolumn{2}{|c|}{1996} \\
\hline & & $1988-1993$ & 1996 & 1988-1993 & 1996 & 1988-1993 & 1996 & \multirow{2}{*}{$\begin{array}{l}\text { Number of } \\
\text { examination }\end{array}$} & \multirow{2}{*}{$\mathrm{n}$} & \multirow{2}{*}{$\begin{array}{l}\text { Number of } \\
\text { examination }\end{array}$} & \multirow{2}{*}{$\mathrm{n}$} \\
\hline & & $\mathrm{n}$ & $\mathrm{n}$ & $\mathrm{n}$ & $\mathrm{n}$ & $\mathrm{n}$ & $\mathrm{n}$ & & & & \\
\hline 1.0 & & 2 & - & - & 1 & - & - & 3 & 2 & 1 & 1 \\
\hline 2.0 & & 32 & 3 & 9 & 5 & 5 & 6 & 46 & 61 & 20 & 14 \\
\hline 2.5 & & - & - & - & - & 7 & 5 & 7 & 12 & 10 & 5 \\
\hline 3.0 & & 40 & 3 & 8 & 2 & 3 & 8 & 73 & 51 & 25 & 13 \\
\hline 3.5 & & - & - & - & - & 4 & 7 & 6 & 4 & 18 & 7 \\
\hline 4.0 & & 25 & 5 & 4 & 17 & 1 & 14 & 40 & 30 & 62 & 36 \\
\hline 4.5 & & - & - & - & - & 5 & 11 & 8 & 5 & 24 & 11 \\
\hline 5.0 & & 11 & 1 & 5 & 5 & 1 & 6 & 21 & 17 & 19 & 12 \\
\hline 5.5 & & - & - & - & - & 1 & 2 & 2 & 1 & 5 & 2 \\
\hline 6.0 & & 3 & 3 & - & 2 & 1 & 4 & 6 & 4 & 13 & 9 \\
\hline 6.5 & & - & - & - & - & - & 1 & - & - & 2 & 1 \\
\hline 7.0 & & - & - & - & 2 & - & - & - & - & 2 & 2 \\
\hline 8.0 & & 1 & - & - & - & - & - & 1 & 1 & - & - \\
\hline 9.0 & & 1 & - & - & - & - & - & 1 & 1 & - & - \\
\hline Total & $\mathrm{n}$ & 115 & 15 & 26 & 34 & 28 & 64 & 214 & 169 & 201 & 113 \\
\hline mean & $x$ & 3.26 & 3.87 & 3.19 & 3.40 & 3.34 & 3.90 & 3.19 & 3.83 & 4.27 & 3.89 \\
\hline$\geq 4$ & $\mathrm{n}$ & 41 & 9 & 9 & 26 & 9 & 38 & 79 & 59 & 127 & 73 \\
\hline & $\%$ & 36 & 60 & 35 & 76 & 32 & 59 & 37 & 35 & 63 & 65 \\
\hline
\end{tabular}


Table 2

Progeny testing of rams by the ovulation rate (OR) of their daughters in 1988-1993

\begin{tabular}{|c|c|c|c|c|c|c|c|c|c|c|}
\hline \multirow{3}{*}{ Year } & \multirow{3}{*}{ Ram's number } & \multirow{3}{*}{$\begin{array}{l}\text { Ram's } \\
\text { sire } \\
\text { number }\end{array}$} & \multirow{3}{*}{$\begin{array}{l}\text { Ram's } \\
\text { dam } \\
\text { number }\end{array}$} & \multirow{3}{*}{$\begin{array}{c}\text { Dam's } \\
\text { mean } \\
\text { OR }\end{array}$} & \multirow{3}{*}{$\begin{array}{l}\text { Dam's } \\
\text { sire } \\
\text { number }\end{array}$} & \multicolumn{4}{|c|}{ Daughters } & \multirow{3}{*}{$\begin{array}{c}\text { Classifi- } \\
\text { cation }\end{array}$} \\
\hline & & & & & & \multirow{2}{*}{$\mathrm{n}$} & \multirow{2}{*}{$\begin{array}{c}\text { mean } \\
\text { OR }\end{array}$} & \multicolumn{2}{|c|}{$\mathrm{OR} \leq 3$} & \\
\hline & & & & & & & & $\mathrm{n}$ & $\%$ & \\
\hline 1988 & 3118 & $1232 \mathrm{~F}+$ & $32 / 79$ & 4.4 & $1421 \mathrm{FF}$ & 38 & 2.26 & 13 & 34 & $\mathrm{~F}+$ \\
\hline 1988 & 63 & $334 / 83 \mathrm{~F}+$ & 2288 & 4.3 & $1250 \mathrm{~F}+$ & 32 & 2.31 & 9 & 28 & $\mathrm{FF}$ \\
\hline \multirow[t]{2}{*}{1988} & 64 & $334 / 83 \mathrm{~F}+$ & 2288 & 4.3 & $1250 \mathrm{~F}+$ & 43 & 2.67 & 17 & 39 & $\mathrm{FF}$ \\
\hline & Merino control ++ & - & - & - & - & 15 & 1.07 & - & - & ++ \\
\hline 1988 & 41457 & $052 \mathrm{~F}+$ & 11054 & - & $878 \mathrm{~F}+$ & 11 & 2.75 & 4 & 36 & $\mathrm{~F}+$ \\
\hline 1988 & 51537 & $048 \mathrm{~F}+$ & 1937 & - & $878 \mathrm{~F}+$ & 9 & 2.83 & 4 & 44 & $\mathrm{~F}+$ \\
\hline 1988 & 61 & $3118 \mathrm{~F}+$ & 2178 & 4.33 & $1250 \mathrm{~F}+$ & 14 & 4.14 & 11 & 79 & FF \\
\hline 1990 & 730 & $4187 \mathrm{FF}$ & 42257 & 3.0 & $046 \mathrm{~F}+$ & 8 & 1.25 & 3 & 37 & $\mathrm{~F}+$ \\
\hline 1992 & 844 & $4204 \mathrm{FF}$ & 4148 & 3.0 & $048 \mathrm{~F}+$ & 21 & 2.05 & 7 & 30 & $\mathrm{~F}+$ \\
\hline 1992 & 9195 & $61 \mathrm{FF}$ & 72450 & 3.5 & $045 \mathrm{~F}+$ & 23 & 2.87 & 11 & 48 & $\mathrm{FF}$ \\
\hline 1992 & 0269 & $3244 \mathrm{FF}$ & 72724 & 3.5 & $046 \mathrm{~F}+$ & 22 & 1.63 & 6 & 27 & $\mathrm{~F}+$ \\
\hline \multirow[t]{2}{*}{1992} & 0293 & $61 \mathrm{FF}$ & 72264 & - & $046 \mathrm{~F}+$ & 15 & 2.01 & 4 & 26 & $\mathrm{~F}+$ \\
\hline & Merino ++ & - & - & - & - & 33 & 0.81 & 1 & 3 & ++ \\
\hline 1992 & 910 & $4187 \mathrm{FF}$ & 725 & 2.5 & $920 \mathrm{~F}+$ & 10 & 2.10 & 5 & 50 & $\mathrm{~F}+$ \\
\hline 1992 & 914 & $59 \mathrm{FF}$ & 73287 & 3.0 & $055 \mathrm{~F}+$ & 12 & 2.17 & 4 & 30 & FF \\
\hline 1992 & 952 & $61 \mathrm{FF}$ & 73186 & 3.0 & $046 \mathrm{~F}+$ & 8 & 0.87 & - & - & $\mathrm{F}+$ \\
\hline 1992 & 8105 & $63 \mathrm{FF}$ & 4889 & 3.0 & $048 \mathrm{~F}+$ & 13 & 1.61 & 4 & 31 & $\mathrm{~F}+$ \\
\hline 1992 & 952 & $61 \mathrm{FF}$ & 73186 & 3.0 & $046 \mathrm{~F}+$ & 16 & 2.18 & 6 & 38 & $\mathrm{~F}+$ \\
\hline 1992 & 0173 & $4130 \mathrm{FF}$ & 73361 & 4.0 & $055 \mathrm{~F}+$ & 4 & 4.50 & 4 & 100 & - \\
\hline 1993 & 0159 & $4130 \mathrm{FF}$ & 73121 & 3.0 & $052 \mathrm{~F}+$ & 9 & 2.66 & 5 & 55.5 & $\mathrm{~F}+$ \\
\hline 1993 & 0173 & $4130 \mathrm{FF}$ & 73361 & 4.0 & $055 \mathrm{~F}+$ & 11 & 3.36 & 9 & 81.8 & FF \\
\hline 1993 & 178 & $4130 \mathrm{FF}$ & 61924 & 5.0 & $043 \mathrm{~F}+$ & 10 & 3.62 & 9 & 87.5 & FF \\
\hline
\end{tabular}

$\mathrm{FF}=\mathrm{Fec}^{\mathrm{B}}$ gene homozygous carrier; $\mathrm{F}+=\mathrm{Fec}^{\mathrm{B}}$ gene heterozygous; $++=$ non-carrier 


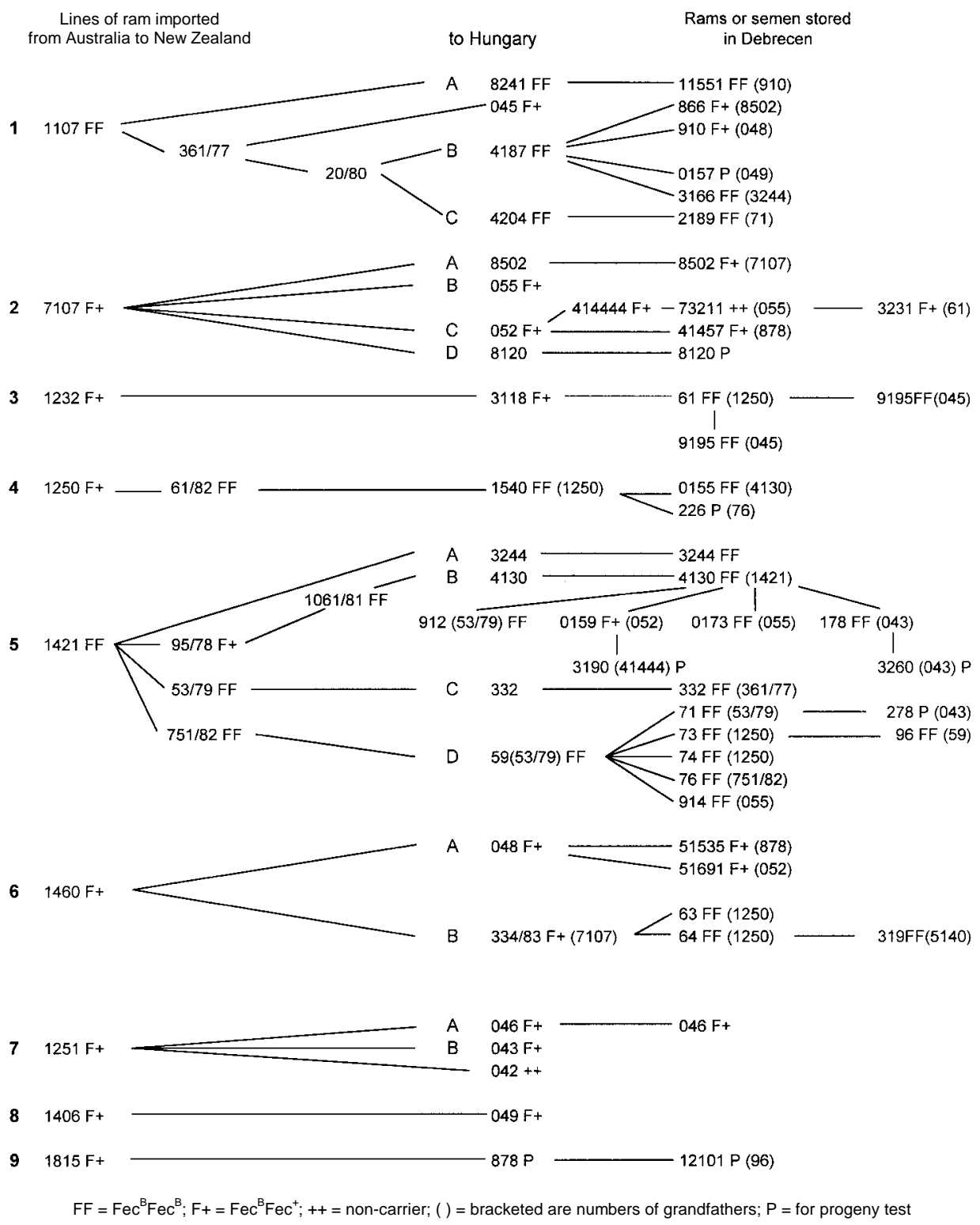

Fig. 1. Prolific ram lines in Hungary (Debrecen)

In the state studs of the former Austro-Hungarian Monarchy a special genealogical linebreeding was applied. A similar linebreeding is used at present in the Hungarian herds, by which inbreeding can be prevented or controlled. To 
establish a similar record system, the male ancestors of the purchased rams were studied. It was concluded that they were the descendants of nine rams which had been taken to New Zealand from Australia (Fig. 1). Two to four offspring from several ram lines were obtained; these are distinguished from each other as 1/A, $1 / B$... etc. sub-lines.

Only two out of the nine rams (no. 1107 and 1421) proved to be homozygous carriers based on their female offspring; the others were heterozygous. In the Haldon Station sheep flock, on the basis of their progeny test we could requalify the home-bred grandchild of the ram that we ranked into the $3^{\text {rd }}$ line (61) and the home-bred grandchildren $(63,64)$ of the 6/B ram line into the $\mathrm{Fec}^{\mathrm{B}} \mathrm{Fec}^{\mathrm{B}}$ genotype. In line 4 the line-establishing sons of the ram of $\mathrm{Fec}^{\mathrm{B}} \mathrm{Fec}^{\mathrm{B}}$ genotype also covered, so his obtained grandchild (no. 5140) also proved to be a homozygous carrier. As a result, at present homozygous gene carrier rams are available in 10 genealogical ram lines. In further six ram lines there are only gene carriers $\left(\mathrm{Fec}^{\mathrm{B}} \mathrm{Fec}^{+}\right)$.

According to Bernardin (1890), only the offspring of the original seven rams covered in the herd purchased from Spain in 1789 and further bred in Rambouillet, and in 100 years there was no deterioration in the animals' performance. The situation has not changed ever since. It is unnecessary to purchase newer Booroola rams and worry about the deterioration caused by the prospective inbreeding. With the available 16 ram-lines long-term inbreeding can be carried out without facing the risks of deterioration due to inbreeding. The phenotype of our present rams is better and their breeding value is higher than that of most imported rams. In the nucleus herd assortative mating was performed (Table 2), mostly in the case of ram establishing line 5 (no. 1421). His offspring from accumulated assortative mating (no. 71, 76, 96) produced excellent offspring when mated with unrelated ewes, despite their poor phenotype. Other rams (no. 043, 052) we also used in assortative mating. Their home progeny test results were considerably better as compared to that of other imported rams' daughters (Veress, 1991; Fig. 2). Similar results were expected of ram no. 8502 born from the mating of father-daughter in 1978, which had his first offspring in the Debrecen flock in 1996/97.

Several Hungarian and foreign Merino sheep farms wishing to introduce the prolific gene into their stock without changing the breed's phenotype can purchase homozygous gene carrier ewes and rams from our stock. The sheep farms under pedigree registration, where OR tests are not performed, can obtain rams of both genotypes from the required line (father) as requested, if they place their order in advance. Frozen semen has been exported to Germany several times $(1989,1994)$. 

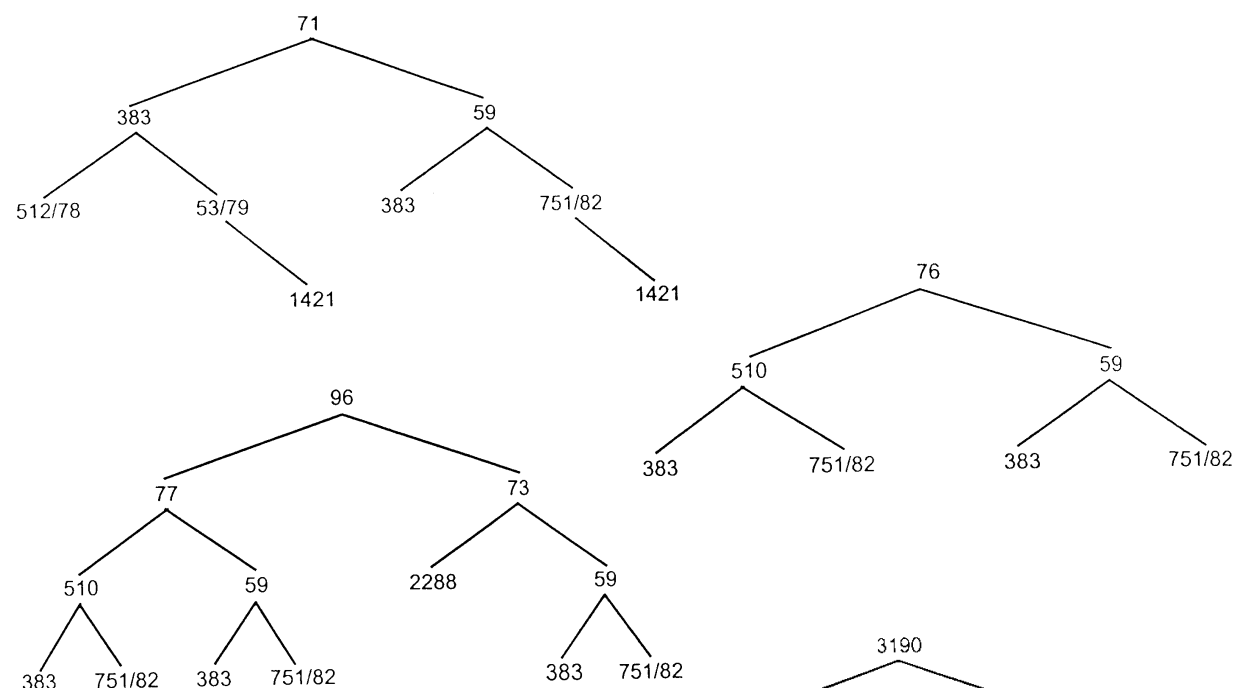

383
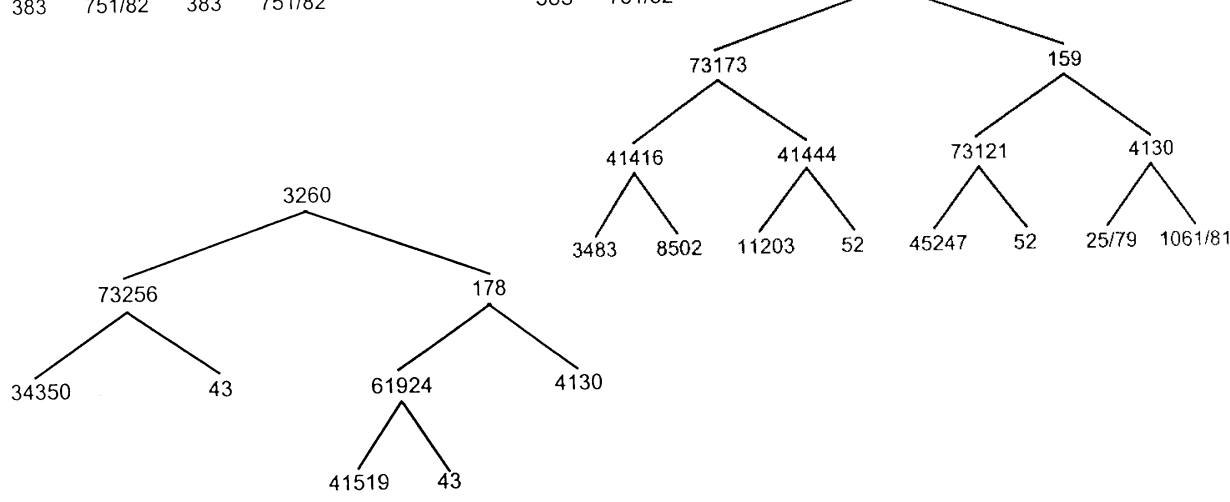

Fig. 2. Origin of inbred Prolific Merino rams

\section{Progeny test}

The genotype of the imported rams participating in the development of the prolific Merino breed was estimated first in 1980 and then in 1982, on the basis of the performance of their daughters from the first crossing. Ram no. 8241 received $\mathrm{Fec}^{\mathrm{B}} \mathrm{Fec}^{\mathrm{B}}$ qualification based on his daughters born in the flock in Siófok (Lengyel, 1989). The $\mathrm{Fec}^{\mathrm{B}} \mathrm{Fec}^{+}$genotype of rams no. 8502, 043, 045, 046, 048, 049,052 and 055 was proven on the basis of their daughters bred on the sheep farm of Csenger. On the basis of its crossbred daughters, ram no. 042 did not prove to be a prolific gene carrier (Veress, 1991).

Progeny tests have not yet been performed for two rams (no. 878 and 8120) born in 1978 and imported in 1980 (Table 4). 
MAGYAR et al.

One out of the eight rams purchased for the breeding program in 1986 (no. 334/83) died in quarantine, but prior to this he had covered an ewe which was a homozygous carrier of the prolific gene and was imported at the same time. (The two rams born from this mating are no. 63-64.) On the basis of their origin they are considered to be only heterozygous carriers. Out of further eight rams (no. 3321, 3118, 3244, 4130, 4187, 4204, 59, 5140), five (no. 332, 4130, 4187, 59, 5140) could be expected to be homozygous by their origin, which assumption proved true on the basis of both their male and female offspring. Ram no. 3118 was qualified to be only a gene carrier $\left(\mathrm{Fec}^{\mathrm{B}} \mathrm{Fec}^{+}\right)$on the basis of his daughters from matings with non-carrier ewes (Table 2). Rams no. 3244 and 4204 were qualified to be homozygous genotypes according to their offspring born in the nucleus stock.

Table 2 presents the progeny test of our rams bred in Hungary based on the early induced OR tests of their daughters from ewes not carrying the prolific gene. Seven out of the 17 rams (no. 61, 63, 64, 914, 9195, 0173, 178) proved to be homozygous gene carriers, while the remaining 10 (no. 41457, 51537, 730, $844,8105,910,952,0159,0269,0293$ ) were heterozygous carriers. Subsequently an early induced OR test performed in Germany for Prolific $\times$ Meat Merino $F_{1}$ rams and Meat Merino ewes' daughters confirmed the homozygous genotype of rams no. 63 and 71 (Table 3).

In the nucleus flock homozygous ewes were inseminated with semen from ram no. 73211. As his daughters proved to be only heterozygous gene carriers on the basis of their OR, the ram had to be qualified as a non-carrier. His son from a homozygous gene carrier ewe having excellent genotype but achieving dubious results was a heterozygous carrier; still, his frozen semen was stored (no. 3231). The frozen semen of rams that are estimated to be homozygous after their parents (no. 73, 74, 76, 96, 912, 2189, 319, 3166, 11551) is also being stored. The progeny tests of other rams have to be evaluated yet (no. 51691, 0157, 226, 278, 3190, 3260, 12101; Fig. 1).

\section{Intrauterine inseminations}

When the nucleus stock in Debrecen was established, only one Booroola Merino ram was purchased. The flock was developed by the use of some young, own-bred rams for covering. The improvement of genetic variability and the conscious development of new ram lines were accomplished by well-planned assortative mating and intrauterine inseminations applied over several years. Between 1986 and 1996, assortative mating using frozen semen from 20 rams of 12 ram lines was performed (Table 5).

Intrauterine insemination is known to be the method of choice when using frozen semen. According to the data presented in relevant handbooks (Salamon, 1976; Evans and Maxwell, 1987), a conception rate of 60-75\% can be achieved 
Table 3

Progeny testing of rams by the OR of their daughters

\begin{tabular}{|c|c|c|c|c|c|c|c|c|c|c|c|c|c|c|}
\hline \multirow{2}{*}{$\begin{array}{l}\text { Ram's } \\
\text { sire } \\
\text { number }\end{array}$} & \multirow{2}{*}{$\begin{array}{l}\text { Ram's } \\
\text { number }\end{array}$} & \multicolumn{9}{|c|}{ OR } & \multicolumn{2}{|c|}{ Total } & \multicolumn{2}{|c|}{$3 \leq$} \\
\hline & & 0 & 1 & 2 & 3 & 4 & 5 & 6 & 7 & 8 & $\mathrm{n}$ & $\mathrm{OR} \bar{x}$ & $\mathrm{n}$ & $\%$ \\
\hline \multirow{6}{*}{61} & 176 & 3 & 3 & 3 & 4 & 1 & - & - & - & - & 14 & 1.78 & 5 & 36 \\
\hline & 479 & 1 & 2 & 3 & 2 & 2 & - & - & - & - & 10 & 2.2 & 4 & 40 \\
\hline & 631 & 3 & 2 & 4 & 1 & 1 & - & - & - & - & 11 & 1.54 & 2 & 18 \\
\hline & 675 & 1 & 1 & 6 & 2 & 2 & - & - & - & - & 12 & 2.25 & 4 & 30 \\
\hline & 829 & 1 & 5 & 2 & - & 2 & - & - & - & - & 10 & 1.7 & 2 & 20 \\
\hline & Total & 9 & 13 & 18 & 9 & 8 & - & - & - & - & 57 & 1.89 & 17 & 30 \\
\hline \multirow{6}{*}{63} & 417 & 3 & 3 & 4 & 6 & - & - & 1 & 1 & - & 18 & 2.33 & 8 & 40 \\
\hline & 635 & 1 & 5 & 6 & 2 & 1 & 1 & - & - & - & 16 & 2.68 & 4 & 25 \\
\hline & 665 & 3 & 3 & 6 & - & 1 & 1 & 2 & - & - & 16 & 2.25 & 4 & 25 \\
\hline & 692 & 4 & 5 & 8 & 3 & 3 & - & - & 1 & - & 24 & 2.04 & 7 & 29 \\
\hline & 844 & 2 & 3 & 7 & 6 & 2 & 1 & 1 & - & - & 22 & 2.45 & 10 & 45 \\
\hline & Total & 13 & 19 & 31 & 17 & 7 & 3 & 4 & 2 & - & 96 & 2.22 & 33 & 34 \\
\hline \multirow{6}{*}{71} & 515 & 2 & 5 & 5 & 2 & 3 & 1 & - & - & 2 & 20 & 2.7 & 6 & 30 \\
\hline & 526 & 2 & 1 & 2 & - & 1 & - & - & - & - & 6 & 1.33 & 1 & 17 \\
\hline & 720 & 3 & 1 & 2 & 1 & - & 2 & - & - & 1 & 10 & 2.6 & 4 & 40 \\
\hline & $816 \mathrm{I}$. & 4 & 4 & 9 & 5 & 5 & 1 & - & - & - & 28 & 2.21 & 11 & 39 \\
\hline & 816 II. & 3 & 3 & 3 & 1 & 3 & 1 & 1 & - & - & 15 & 1.93 & 6 & 40 \\
\hline & Total & 14 & 14 & 21 & 9 & 12 & 5 & 1 & - & 3 & 79 & 2.15 & 30 & 38 \\
\hline
\end{tabular}


when insemination is properly performed. Intrauterine insemination with frozen semen is therefore a routine method in Australia. In the present case the application of the method was necessary because some rams (no. 59, 5140, 61, 3190), which were kept in the ram line due to either their origin or their phenotype, produced very poor fertility results after deep-freezing of their semen. Considering these circumstances, the average conception rate of 53\% is quite a good result. If the results of poor-performing rams are ignored, the conception rate achieved by the other 15 rams is $60 \%$. Salamon et al. (1985) achieved a conception rate of $57-66 \%$ with semen stored for 16 years. Our own experience is in accordance with that from the above-mentioned study, since the conception rates achieved with the semen of rams no. 878, 8241, 8502, stored for 11-12 years, are satisfactory.

Table 4

Predicted value of rams

\begin{tabular}{lccc}
\hline & $\begin{array}{c}\text { Booroola Merino } \\
\text { (from import) }\end{array}$ & $\begin{array}{c}\text { Prolific Merino } \\
\text { (breed in Hungary) }\end{array}$ & Total \\
\hline By origin Fec ${ }^{\mathrm{B}} \mathrm{Fec}^{\mathrm{B}}$ & - & 9 & 9 \\
Based on progeny testing & 8 & 8 & 16 \\
$\quad \mathrm{Fec}^{\mathrm{B}} \mathrm{Fec}^{\mathrm{B}}$ & 10 & 11 & 21 \\
$\mathrm{Fec}^{\mathrm{B}} \mathrm{Fec}^{+}$ & 1 & 1 & 2 \\
$\mathrm{Fec}^{+} \mathrm{Fec}^{+}$ & 2 & 7 & 9 \\
Before testing & 21 & 36 & 57 \\
\hline Total & & & \\
\hline
\end{tabular}

Individual ejaculates varied widely in terms of fertility. There were more pronounced differences in the conception results between individual rams than between different times of the year.

In the autumn of 1993, 28 Prolific Merino ewes were inseminated with frozen semen from a young, 10-month-old Texel ram imported from Germany, with a conception rate of $64 \%$. Further 30 ewes were inseminated with the fresh semen of the same ram by the intrauterine route, and the conception rate was only $42 \%$.

It is a valuable trait of the Prolific Merino breed that it is capable of ovulation and conception for years, and that it can be lambed frequently. The rams' relatively stable semen production also supports this statement.

By this method, eight out of the rams in the stock (89\%) and $54 \%$ of the ewes were born as a result of intrauterine insemination. The ewes in the stock are the offspring of 19 different rams.

For rams with excellent progeny test results the extra expenses of intrauterine insemination are compensated by the substantial genetic improvement achieved. 
Table 5

Results of intrauterine insemination (Debrecen, 1986-1996)

\begin{tabular}{|c|c|c|c|c|c|c|c|c|c|}
\hline \multirow{2}{*}{ No. } & \multirow{2}{*}{ Ram's line } & \multirow{2}{*}{$\begin{array}{c}\text { Number of } \\
\text { ram }\end{array}$} & \multirow{2}{*}{$\begin{array}{c}\text { Ram's sire } \\
\text { number }\end{array}$} & \multirow{2}{*}{ Dam's OR } & \multirow{2}{*}{$\begin{array}{l}\text { Dam's sire } \\
\text { number }\end{array}$} & \multirow{2}{*}{$\frac{\text { Inseminated }}{\mathrm{n}}$} & \multicolumn{2}{|c|}{ Fertility } & \multirow{2}{*}{ Origin } \\
\hline & & & & & & & $\mathrm{n}$ & $\%$ & \\
\hline 1 & $1 \mathrm{~A}$ & $8241 \mathrm{FF}$ & $1107 \mathrm{FF}$ & 3 & - & 13 & 7 & 54 & import \\
\hline 2 & 1B & $4187 \mathrm{FF}$ & $20 / 80 \mathrm{FF}$ & 5 & $70 / 70 \mathrm{FF}$ & 65 & 31 & 48 & import \\
\hline 3 & 1B & $866 \mathrm{~F}+$ & $4187 \mathrm{FF}$ & 3 & $8502 \mathrm{~F}+$ & 6 & 4 & 67 & $*$ \\
\hline 4 & $1 \mathrm{C}$ & $4204 \mathrm{FF}$ & $20 / 80 \mathrm{FF}$ & 4 & $189 / 75 \mathrm{FF}$ & 17 & 8 & 47 & import \\
\hline 5 & $2 \mathrm{~A}$ & $8502 \mathrm{~F}+$ & $07 / 71 \mathrm{~F}+$ & 3 & 07/71 F+ & 24 & 13 & 54 & import \\
\hline 6 & $2 \mathrm{C}$ & $73211++$ & $41444 \mathrm{~F}+$ & 3 & $055 \mathrm{~F}+$ & 16 & 9 & 56 & $*$ \\
\hline 7 & 3 & $3118 \mathrm{~F}+$ & $1232 \mathrm{~F}+$ & 4.4 & $1421 \mathrm{FF}$ & 10 & 7 & 70 & import \\
\hline 8 & 3 & $61 \mathrm{FF}$ & $3118 \mathrm{~F}+$ & 4.4 & $1250 \mathrm{~F}+$ & 9 & 2 & 22 & $*$ \\
\hline 9 & 4 & $5140 \mathrm{FF}$ & $61 / 82 \mathrm{FF}$ & 4.3 & $1250 \mathrm{~F}+$ & 33 & 12 & 36 & import \\
\hline 10 & 4 & $226 \mathrm{P}$ & $5140 \mathrm{FF}$ & 3.5 & $76 \mathrm{FF}$ & 39 & 20 & 51 & * \\
\hline 11 & $5 B$ & $4130 \mathrm{FF}$ & $1061 / 80 \mathrm{FF}$ & 5.8 & $1421 \mathrm{FF}$ & 61 & 50 & 82 & import \\
\hline 12 & $5 B$ & $0173 \mathrm{FF}$ & $4130 \mathrm{FF}$ & 4 & $055 \mathrm{~F}+$ & 2 & 1 & 50 & $*$ \\
\hline 13 & $5 B$ & $3190 \mathrm{P}$ & $0159 \mathrm{~F}+$ & 4.5 & $41444 \mathrm{~F}+$ & 43 & 11 & 26 & $*$ \\
\hline 14 & $5 B$ & $3260 \mathrm{P}$ & $178 \mathrm{FF}$ & 3 & $043 \mathrm{~F}+$ & 32 & 18 & 56 & $*$ \\
\hline 15 & $5 \mathrm{C}$ & $332 \mathrm{FF}$ & $53 / 79 \mathrm{FF}$ & 6 & $361 / 77 \mathrm{FF}$ & 54 & 32 & 59 & import \\
\hline 16 & $5 \mathrm{D}$ & $59 \mathrm{FF}$ & $751 / 82 \mathrm{FF}$ & 5 & 53/79 FF & 10 & 1 & 10 & import \\
\hline 17 & $5 \mathrm{D}$ & $71 \mathrm{FF}$ & $59 \mathrm{FF}$ & 5 & $53 / 79 \mathrm{FF}$ & 1 & 1 & 100 & $*$ \\
\hline 18 & $5 \mathrm{D}$ & $278 \mathrm{P}$ & $71 \mathrm{FF}$ & 3 & $043 \mathrm{~F}+$ & 2 & 1 & 50 & $*$ \\
\hline 19 & $6 \mathrm{~B}$ & $64 \mathrm{FF}$ & $334 / 83 \mathrm{~F}+$ & 4.3 & $1250 \mathrm{~F}+$ & 33 & 19 & 57 & $*$ \\
\hline 20 & 9 & $878 \mathrm{P}$ & $1815 / 76-$ & - & - & 2 & 2 & 100 & import \\
\hline \multicolumn{6}{|c|}{ Total } & 472 & 249 & 53.0 & \\
\hline
\end{tabular}

$\mathrm{FF}=\mathrm{Fec}^{\mathrm{B}}$ homozygous carrier; $\mathrm{F}+=\mathrm{Fec}^{\mathrm{B}}$ heterozygous carrier; $++=$ non-carrier; $\mathrm{P}=$ for progeny test; $*$ = bred in Hungary 


\section{References}

Bernardin, L. (1890): La bergerie de Rambouillet et les Merinos. Paris.

Cleverdon, J. M. and Hart, D. S. (1981): Oestrus and ovarian activity of Booroola Merino crossbred ewe hoggets. Proceeding N. Z. Soc. Anim. Prod. 41, 189-192.

Davis, G. H. and Johnstone, P. D. (1985): Ovulation response to pregnant mares serum gonadotrophin in prepubertal lambs of different Booroola genotypes. Anim. Repr. Sci. 9, 145-151.

Davis, G. H. and Kelly, R. W. (1983): Segregation of a major gene influencing ovulation rate in progeny of Booroola sheep in commercial and research flock. Proceeding N. Z. Society Animal Production 43, 192-197.

Dodds, K. G., Davis, G. H., Elsen, J. M., Isaac, K. L. and Owens, J. L. (1991): The effect of Booroola genotype on some reproduction traits in Booroola Merino flock. In: Elsen, J. M., Bodin, L. and Thimonier, J. (eds) Major Genes for Reproduction in Sheep. $2^{\text {nd }}$ International Workshop, 57, INRA, Paris, pp. 359-366.

Evans, G. and Maxwell, W. M. C. (1987): Salamon's Artifical Insemination of Sheep and Goats. Butterworths, London.

Hulet, C. W. and Foot, W. G. (1968): A rapid technique for observing the reproductive tract of living ewes. J. Anim. Sci. 27, 142-145.

Killen, I. D. and Caffery, G. J. (1982): Uterine insemination of ewes with the aid of a laparoscope. Austr. Vet. J. 59, 95.

Lengyel, A. (1989): Utilisation of individual, maternal and complementary heterosis in sheep breeding programs. PhD Dissertation, Hungarian Academy of Sciences, Budapest.

Magyar, K. (1988): Laparoscopy of ovaries in ewes and hoggets (in Hungarian, with English abstract). Magyar Állatorvosok Lapja 43, 93-95.

Magyar, K., Veress, L. and Komlósi, I. (1989a): Insemination with frozen semen in Booroola by the endoscopic method. $39^{\text {th }}$ Annual Meeting of EAAP Dublin, Ireland.

Magyar, K., Komlósi, I. and Veress, L. (1989b): Laparoscopic intrauterine insemination of sheep with deep-frozen semen (in Hungarian, with English abstract). Magyar Állatorvosok Lapja 44, 475-477.

Magyar, K., Komlósi, I. and Veress, L. (1991): Progeny testing of Booroola rams for the F gene using prepubertal ewe lambs. In: Elsen, J. M., Bodin, L. and Thimonier, J. (eds) Major Genes for Reproduction in Sheep. $2^{\text {nd }}$ International Workshop, 57, INRA, Paris, pp. 167-170.

Magyar, K. (1994): New insemination pipette for the intrauterine laparoscopic insemination of sheep (in Hungarian, with English abstract). Magyar Állatorvosok Lapja 49, 478-479.

Magyar, K., Veress, L., Tasi, Zs., Pécsi, T., Horváthné, I. and Babik, S. (1997): A sheep breeding program and results to date II (in Hungarian). Állattenyésztés és Takarmányozás 46, 41-50.

McKelvey, W. A. C., Robinson, J. J. and Aitken, R. P. (1985): Repeated recoveries of ovine ova by laparoscopy. Theriogenology 24, 519-535.

Oldham, C. M., Gray, S. J., Poindron, P. and Bindon, B. M. (1984): Progeny testing for the F gene using prepubertal ewe lambs. In: Lindsay, D. R. and Pearce, D. T. (eds) Reproduction in Sheep. Cambridge Univ. Press. pp. 260-264.

Piper, L. R. and Bindon, B. M. (1982): Genetic segregation for fecundity in Booroola Merino sheep. In: Proc. of the World Congr. on Sheep and Beef Cattle Breeding. I. The Dunmore Press, Palmerston North, pp. 395-400.

Piper, L. R., Bindon, B. M. and Davis, G. H. (1985): The single gene inheritance of the prolificacy of the Booroola Merino. In: Land, R. B. and Robinson, D. W. (eds) The Genetics of Reproduction in Sheep. Butterworths, London, pp. 115-125.

Salamon, S. (1976): Artifical Insemination of Sheep. Sydney Publicity Press Ltd.

Salamon, S., Maxwell, W. M. C. and Evans, G. (1985): Fertility of ram semen frozen-stored for 16 years. Proc. $7^{\text {th }}$ Annual Conference Australian Society Reproduction Biology, p. 62. 
Tasi, Zs., Resli, I. and Jakab, F. (1984): Experiences with deep-frozen ram's semen (in Hungarian). Állattenyésztés és Takarmányozás 33, 245-249.

Veress, L. (1991): Genetic and keeping technology questions involved in the development of sheep breeding. D.Sc. Dissertation, Hungarian Academy of Sciences, Budapest.

Veress, L., Kovács, Z. and Komlósi, I. (1993): Examination of the effect influencing the lambing period of two Hungarian Merino Variants. $44^{\text {th }}$. EAAP. Aarhus S. s., 7.

Veress, L., Magyar, K., Komlósi, I., Horváth, V. (Mrs) and Kovács, Z. (1995): A sheep breeding program and results to date (in Hungarian). Állattenyésztés és Takarmányozás 44, 301-315. 

